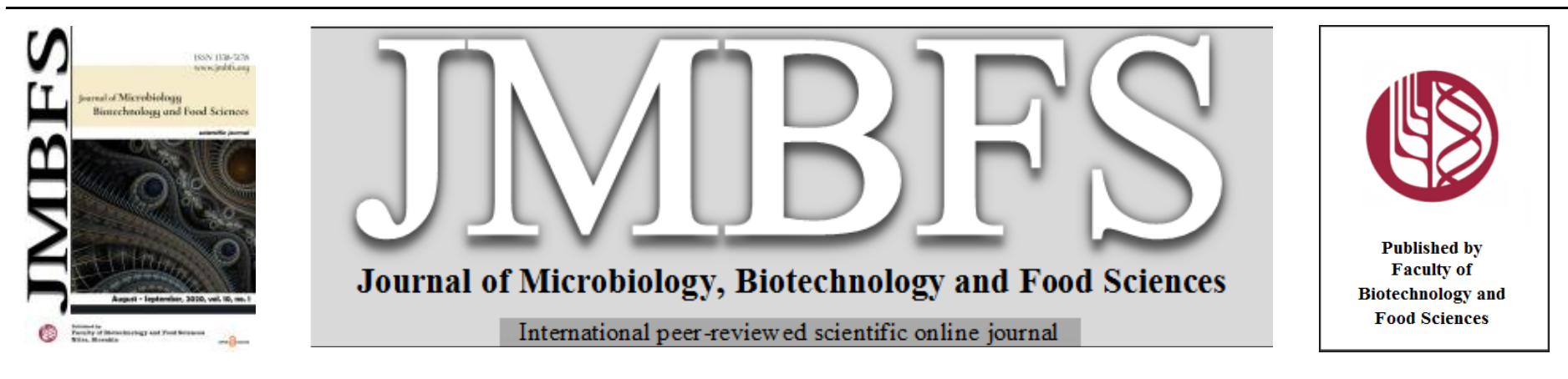

\title{
LEVAN PRODUCTION POTENTIALS FROM DIFFERENT HYPERSALINE ENVIRONMENTS IN TURKEY
}

\author{
Hakan Çakmak ${ }^{1}$, Pınar Aytar Çelik*2,3, Seval Çınar ${ }^{4}$,Emir Zafer Hoşgün ${ }^{5}$, M. Burçin Mutlu ${ }^{4}$, Ahmet Çabuk ${ }^{6}$
}

\author{
$\operatorname{Address}(e s):$ \\ ${ }^{1}$ Department of Biotechnology and Biosafety, Eskişehir Osmangazi University, Eskişehir, Turkey. \\ ${ }^{2}$ Department of Biomedical Engineering, Eskişehir Osmangazi University, Eskişehir, Turkey. \\ ${ }^{3}$ Horse Breeding Vocational School, Eskișehir Osmangazi University, Eskișehir, Turkey. \\ ${ }^{4}$ Department of Biology, Eskişehir Technical University, Eskişehir, Turkey. \\ ${ }^{5}$ Department of Chemical Department, Eskişehir Technical University, Eskişehir, Turkey. \\ ${ }^{6}$ Department of Biology, Eskişehir Osmangazi University, Eskişehir, Turkey.
}

*Corresponding author: pinaraytar@gmail.com

doi: 10.15414/jmbfs.2020.10.1.61-64

\section{ARTICLE INFO}

Received 9. 12. 2019

Revised 12.3. 2020

Accepted 12.3. 2020

Published 1. 8. 2020

Regular article

open $\mathcal{O}$ access

\begin{abstract}
12 halophilic strains from different hypersaline environments such as solar salterns in Tuzlagözü (Sivas), Fadlum (Sivas), Kemah (Erzincan), a hypersaline spring water in Pülümür (Tunceli) and a saline lake in Delice (Kırıkkale) belonging to Turkey, were investigated in terms of levan production. After incubation and ethyl alcohol treatment, dialysis process was operated for partial purification. Levan amounts in our samples after hydrolysis were calculated based on the amount of sugar obtained by acid hydrolysis of standard levan. Sugar amount of samples were determined using by high performance liquid chromatography system (HPLC). ${ }^{1} \mathrm{H}-$ Nuclear Magnetic Resonance ( $\left.{ }^{1} \mathrm{H}-\mathrm{NMR}\right)$ spectra of the levan sample and standard were recorded. The results obtained by HPLC analysis showed that Chromohalobacter canadensis strain 85B had highest production potential as $234.67 \mathrm{mg}$ levan/g biomass. The chemical shifts of ${ }^{1} \mathrm{H}-\mathrm{NMR}$ spectrum of the extracted levan also showed high similarity to those of pure levan isolated from Erwinia herbicola. Furthermore, Marinobacter sp. $163 \mathrm{Y}$ strain also is also capable with regard to levan production. In this study, this strain could yield $230.80 \mathrm{mg} / \mathrm{g}$ levan and this potential was first reported in the literature.
\end{abstract}

Keywords: halophilic, levan, screening

\section{INTRODUCTION}

Microbial exopolysaccharides (EPS) are one of the major groups of biopolymers and they have unique functions; therefore many biopolymers are already being produced commercially on large scales. As a result, EPSs have increased attraction because of industrial and medical applications (Rehm, 2010). Among of microbial polysaccharides; pullulan, xanthan, dextran, levan have long been the focus of interest owing to extraordinary characteristics (Iyer et al., 2006).

The one of significant EPSs, levan is a $\beta(2-6)$-linked fructose homopolysaccharide that is extracellularly generated from sugar-based substrates by various microorganisms such as species of Zymomonas, Aerobacter, Erwinia, Bacillus, Acetobacter, Azotobacter, Corynebacterium, Mycobacterium, Gluconobacter, Streptococcus, and Pseudomonas. Levan's distinguishing properties including water solubility, film-forming ability, high solubility in oil, strong adhesivity, compatibility with salts and surfactants, low viscosity, heat stability, acid-alkaline stability and high holding capacity for water and chemicals, and good biocompatibility, make this molecule attractive (Kang $\boldsymbol{e t}$ al. 2009; Kazak et al., 2010; Nakaponga et al., 2013). Thereby it has large potential uses as stabilizer, emulsifier, thickener, encapsulating agent, osmoregulator, food and feed additive, cryoprotector in various sectors, plasma substitute, prolongator of drug activity, source of prebiotic fibre, antitumor, antidiabetic and antihyperlipidemic agent in medicine (Kang et al., 2009; Freitas et al., 2011; Sezer et al., 2011; Jathore et al., 2012; Esawy et al., 2013). This polymer is not still cost-effective polymer due to low productivities of the commercially employed microbial systems. Thereby microbial systems having high level levan production capacity are siginificant industrially. In this context, halophilic isolates as well as Halomonas maura, H.ventosae, H.cerina have been considered as outstanding producers (Arias et al., 2003; Mata et al., 2006; Gonzalez-Domenech, 2008; Poli et al., 2009). Because of the fact that the genus of Halomonas is the best extremophilic levan producer, research trend has been focused to combine the benefits of osmoadaptation and halophilicity to favour a cost-effective and eco-friendly levan production procedure, minimize contamination risk and gain novel and valuable characteristics for exopolysaccharide (Poli et al., 2009).

The target of this work was to define the yields of levan for some isolates from different salterns of Turkey. For this purpose, several halophilic isolates were screened quantitatively in terms of levan exopolysaccharide production and characterized.

\section{MATERIAL AND METHODS}

\section{Isolation of microorganisms}

The halophilic strains examined in this study were previously obtained from different hypersaline environments in Turkey solar salterns in Tuzlagözü (Sivas), Fadlum (Sivas), Kemah (Erzincan), hypersaline spring water in Pülümür (Tunceli) and a saline lake in Delice (Kırıkkale) (Çınar et al., 2016). Detailed information on the sources of the isolates is shown in Table 1. Isolations of the strains were performed on modified growth medium (MGM) and R2A medium. MGM was supplemented with $0.5 \%$ peptone, $0.1 \%$ yeast extract and $12 \%, 18 \%$, 23\%, 25\% total salt concentration (Dyall-Smith, 2009). R2A medium [g/L: yeas extract 0.5 , protease peptone 0.5 , casamino acids 0.5 , glucose 0.5 , soluble starch 0.5 , Na-pyruvate $0.3, \mathrm{~K}_{2} \mathrm{HPO}_{4} 0.3, \mathrm{MgSO}_{4} \times 7 \mathrm{H}_{2} \mathrm{O}$ 0.05] was supplemented with $20 \% \mathrm{NaCl}$. Genomic DNAs of the isolates were extracted by boiling. Polymerase chain reaction (PCR) amplification products of the 16S rRNA genes were obtained from DNA samples of the isolates. $27 \mathrm{~F}\left(5^{\prime}\right.$ AGAGTTTGATCATGGCTCAG-3') and 1492R(5' GGTTACCTTGTTACGACTT-3') were used as PCR primers specific for Bacteria domain (Lane et al., 1985). The PCR conditions were used for amplification: a cycle of $94{ }^{\circ} \mathrm{C}$ for $3 \mathrm{~min}, 30$ cycles of $94{ }^{\circ} \mathrm{C}$ for $15 \mathrm{~s}, 55^{\circ} \mathrm{C}$ for $30 \mathrm{~s}$, and $72{ }^{\circ} \mathrm{C}$ for $2 \mathrm{~min}$; finally an extension step of $7 \mathrm{~min}$ at $72{ }^{\circ} \mathrm{C}$ (Mutlu et al., 2008). After PCR products belonging to $16 \mathrm{~S}$ rRNA genes were purified with Wizard® SV Gel and PCR Clean-Up System (Promega), the purified products were sequenced by using CEQ DTCS Kit (Dye Terminator Cycle Sequencing Quick Start Kit, Beckman Coulter) and CEQ ${ }^{\mathrm{TM}} 8000$ DNA sequencer (Beckman Coulter). All sequences were compared with the sequences available in database 
of GenBank (using BLAST program) and Ribosomal Database Project (RDP).

The sequences were submitted to GenBank database.

Table 1 Halophilic bacteria isolated from different salterns

\begin{tabular}{|c|c|c|c|c|}
\hline Species & $\begin{array}{l}\text { Sequence } \\
\text { length }\end{array}$ & Accession no & Isolation field & Medium \\
\hline Marinobacter sp. 163Y & $1501 \mathrm{bp}$ & KP795380.1 & Tuzlagözü saltern, Sivas & $\mathrm{R} 2 \mathrm{~A}$ \\
\hline Halomonas caseinilytica strain $\mathrm{KB} 2$ & 1419 bp & KF668253.1 & Kemah saltern, Erzincan & $18 \% \mathrm{MGM}$ \\
\hline Halomonas variabilis strain T1PU & 1359 bp & KJ161496.1 & Pülümür hypersaline spring water, Tunceli & $12 \% \mathrm{MGM}$ \\
\hline Halomonas ventosae strain $\mathrm{T} 2 \mathrm{PU}$ & $1306 \mathrm{bp}$ & KJ161487.1 & Pülümür hypersaline spring water, Tunceli & $12 \% \mathrm{MGM}$ \\
\hline Halomonas sp. T7PU & 1309 bp & KJ161489.1 & Pülümür hypersaline spring water, Tunceli & $12 \% \mathrm{MGM}$ \\
\hline Halomonas sp. K15 & 1494 bp & KP795384.1 & Kemah saltern, Erzincan & $18 \%$ MGM \\
\hline Halomonas organivorans strain DB4 & 1419 bp & KF668255.1 & Delice saline lake, Kırıkkale & $18 \%$ MGM \\
\hline Halomonas sp. DB5 & 1348 bp & KY099605.1 & Delice saline lake, Kırıkkale & $12 \% \mathrm{MGM}$ \\
\hline Chromohalobacter canadensis strain 85B & $1408 \mathrm{bp}$ & KF668261.1 & Fadlum saltern, Sivas & $23 \% \mathrm{MGM}$ \\
\hline Halomonas alkaliphila strain 305B & 1373 bp & KF985241.1 & Tuzlagözü saltern, Sivas & $12 \% \mathrm{MGM}$ \\
\hline Idiomarina sp. 30BE & $1465 \mathrm{bp}$ & KF976353.1 & Tuzlagözü saltern, Sivas & $18 \% \mathrm{MGM}$ \\
\hline Halomonas elongata strain 153B & 1395 bp & KF668257.1 & Fadlum saltern, Sivas & $25 \% \mathrm{MGM}$ \\
\hline
\end{tabular}

\section{Levan Production}

12 isolates were screened for levan production on the basal medium $(\mathrm{pH} 7)$ consisted of (per liter): $137.2 \mathrm{~g} \mathrm{NaCl} ; 50 \mathrm{~g}$ sucrose; $7 \mathrm{~g} \mathrm{~K}_{2} \mathrm{HPO}_{4} ; 2 \mathrm{~g} \mathrm{KH}_{2} \mathrm{PO}_{4} ; 1$ $\mathrm{g}\left(\mathrm{NH}_{4}\right)_{2} \mathrm{SO}_{4} ; 0.1 \mathrm{~g} \mathrm{MgSO}_{4} .7 \mathrm{H}_{2} \mathrm{O}, 0.32 \mathrm{~g} ; 0.5 \mathrm{~g}$ peptone (Küçükaşik et al. 2011). Sterilization was carried out at $110^{\circ} \mathrm{C}$ for $25 \mathrm{~min}$. After inoculation, the flasks were incubated for $72 \mathrm{~h}$ at $37^{\circ} \mathrm{C}$ and 180 r.p.m. and the working volume was $50 \mathrm{~mL}$. All the experiments were performed in duplicate.

\section{Purification of Levan}

After the incubation period, the polymer medium was transferred to the tubes and then centrifuged at 10.000 r.p.m. for $25 \mathrm{~min}$. The supernatant obtained at the end of the centrifugation was treated with an equal volume of ethyl alcohol and left at $-18{ }^{\circ} \mathrm{C}$ overnight. Then the alcohol-treated solutions were centrifuged at 10.000 r.p.m for $25 \mathrm{~min}$ and the supernatants were discarded. Pellets were dissolved by adding boiling water. For dialysis, Sigma D9777 coded membrane was used. The warmed solution was transferred to the dialysis membrane prepared overnight with distilled water. The membrane was then placed in a container containing $250 \mathrm{ml}$ of distilled water. Dialysis process was continued to 48 hours. After the dialysis, the biopolymer transferred to centrifuge tubes was kept overnight at -80 ${ }^{\circ} \mathrm{C}$ and lyophilized.

\section{Quantification of Levan}

Levan amounts in the samples were calculated based on the amount of sugar obtained by acid hydrolysis of standard levan from Erwinia herbicola (Sigma Aldrich).

The levan produced in this study and the commercial levan samples were subjected to acid hydrolysis for $60 \mathrm{~min}$ at $100{ }^{\circ} \mathrm{C}$ using $6 \mathrm{M} \mathrm{H}_{2} \mathrm{SO}_{4}$. After acid hydrolysis of levan samples, the $\mathrm{pH}$ of the mixture was neutralized by the addition of $\mathrm{NaOH}$. Sugar amounts of samples were determined using HPLC system.

The HPLC system (Agilent 1100, Germany) was equipped with a Bio-Rad Aminex HPX-87P (USA) column $(300 \mathrm{~mm} \times 7.8 \mathrm{~mm})$ and a refractive index detector. The analytical column was operated at $80{ }^{\circ} \mathrm{C}$ with $0.2-\mu \mathrm{m}$ filtered HPLC grade water as the mobile phase. The mobile phase flow rate was 0.6 $\mathrm{mL} / \mathrm{min}$.

\section{NMR Analysis}

All liquid state proton $\left({ }^{1} \mathrm{H}\right)$ NMR spectra of the levan produced in this study and commercial levan obtained from Erwinia herbicola were recorded on a JEOL ECZ 500R spectrometer at usual probe temperature. The operating frequencies were $500.13 \mathrm{MHz}$ for $1 \mathrm{H}$ nucleus.

\section{RESULTS AND DISCUSSION}

\section{Screening of Levan Yields}

Twelve isolates obtained from various places in Turkey were investigated in respect to exopolysaccharide production. These isolates were grown in polymer medium including $13.7 \% \mathrm{NaCl}$. The strains of the Halomonas, Marinobacter, Idiomarina and Chromohalobacter were obtained and screened for the production levels of exopolysaccharides (EPS) (Table 2)
Table 2 Levan yield of the isolates

\begin{tabular}{lc}
\hline Strains & Levan yield (mg Levan/g) \\
\hline Halomonas ventosae strain T2PU & 185.50 \\
Halomonas sp. DB5 & 195.59 \\
Halomonas variabilis strain T1PU & 199.14 \\
Halomonas sp. K15 & 208.27 \\
Halomonas alkaliphila strain 305B & 209.92 \\
Halomonas sp. T7PU & 211.97 \\
Halomonas organivorans strain DB4 & 214.81 \\
Idiomarina sp. 30BE & 216.33 \\
Halomonas caseinilytica strain KB2 & 223.90 \\
Halomonas elongata strain 153B & 226.00 \\
Marinobacter sp. 163Y & 230.80 \\
Chromohalobacter canadensis strain 85B & 234.67 \\
\hline
\end{tabular}

In our study, the results obtained by HPLC analysis showed that Chromohalobacter canadensis strain $85 \mathrm{~B}$ had highest production potential as $234.67 \mathrm{mg}$ levan/g biomass. According to the study of Radchenkova and colleagues, Chromohalobacter canadensis strain 28 isolated from Pomorie salterns could be used as extracellular polymer substance (EPS) producer (Radchenkova et al., 2018). Chemical analysis of the purified polymer indicated that this compound included EPS fraction $(14.3 \% \mathrm{w} / \mathrm{w})$ and protein fraction $(72 \%$ $\mathrm{w} / \mathrm{w})$ including polyglutamic acid (PGA) $(75.7 \% \mathrm{w} / \mathrm{w})$. EPS fraction analysis indicated the following sugar composition (\% w/w): glucosamine 36.7, glucose 32.3, rhamnose 25.4, xylose 1.7, and unidentified sugar 3.9. Although Radchenkova and co-workers mentioned that a strain of Chromohalobacter canadensis could produce extracellular polymer substance, but what type of EPS it produced was specified and was not investigated. In our study, this is the first report for halophilic bacterium such as Chromohalobacter canadensis able to synthesize directly a levan polymer.

Apart from Chromohalobacter canadensis 85B strain, other halophilic bacteria were found to produce levan in the literature. Firstly, a higher yield of EPS was produced by Halomonas smrynensis strain isolated from İzmir province located in the Aegean Region of Turkey (Poli et al., 2013; Ateş et al., 2013). The same strain could produce levan as $8.84 \mathrm{~g} / \mathrm{L}$ based on the spectrophotometric measurement (Sarilmiser et al., 2015). In another study, Halomonas and Chromohalobacter strains were compared with regard to levan production and Chromohalobacter japonicus strains were reported to be more potential levan producers than others (Nasir $\boldsymbol{e t}$ al., 2015). Hussainy and coworkers demonstrated the levan production potential of Chromohalobacter salexigens strains and chemically modified into two derivatives, sulphated and carboxymethylated levan. Three types of biological activities were assayed for levan and its derivatives; anti-tumor activity, fibrinolytic activity and prebiotic activity (Hussainy et al., 2015).

Marinobacter sp. 163Y strain also is also promising in terms of levan production. In this study, this strain could produce $230.80 \mathrm{mg} / \mathrm{g}$ levan. This potential was first reported in the literature.

\section{NMR Analysis}

The chemical shifts of proton NMR spectra of the extracted levan from Chromohalobacter canadensis $85 \mathrm{~B}$ in this study also indicated high similarity to those of levan isolated from Erwinia herbicola (Fig 1a-b). Profile differences may be due to the different bacteria from which the polymer is produced. 


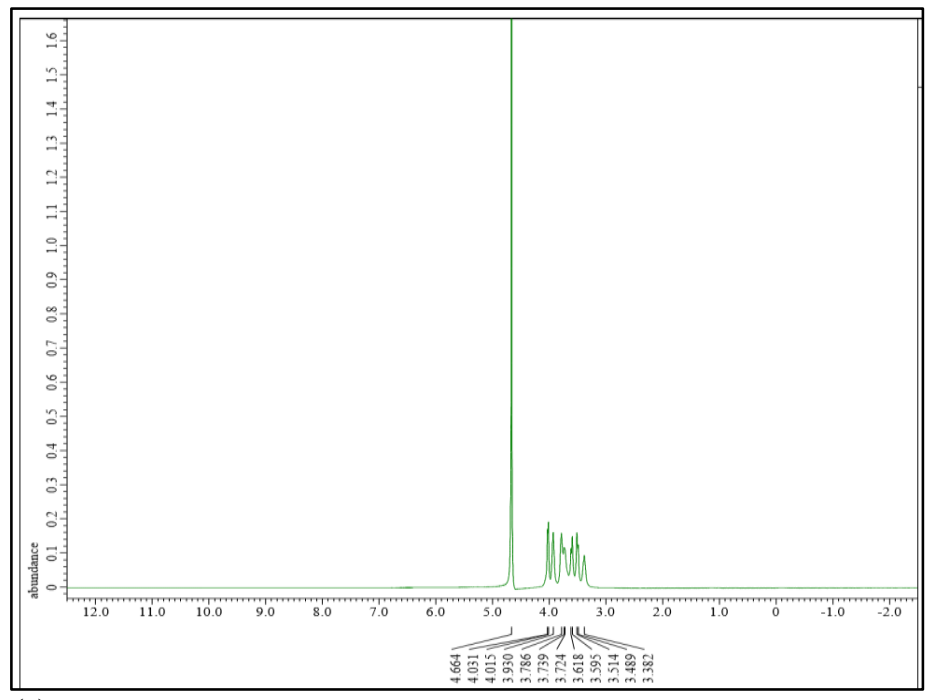

(a)

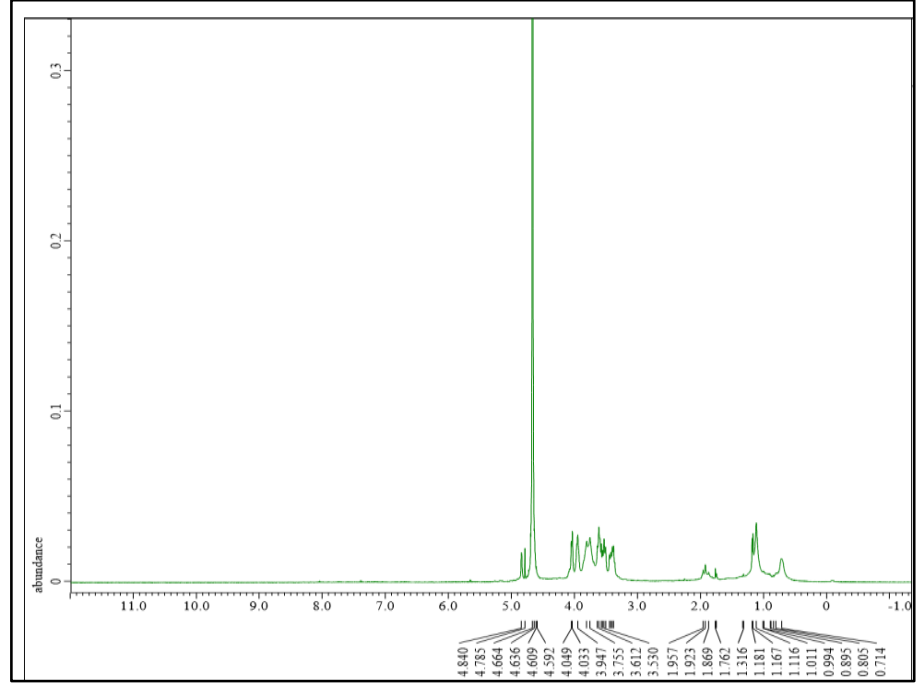

(b)

Figure 1 (a) NMR profile of commercial levan from Erwinia herbicola (b) NMR profile of produced levan from Chromohalobacter canadensis strain 85B

\section{CONCLUSION}

In this study, twelve halophilic strains isolated from different hypersaline fields in Turkey were investigated in terms of levan production abilities. Chromohalobacter canadensis 85B and Marinobacter sp. $163 \mathrm{Y}$ were first reported to synthesize a levan polymer in the literature. Proton NMR profiles of the obtained levan from Chromohalobacter canadensis 85B and commercial levan isolated from Erwinia herbicola indicated high similarity. Further research will be focused on advanced purification and characterization of levan from Chromohalobacter canadensis 85B.

Acknowledgements: The authors would like to thank Dr. Okan Zafer Yeșilel from Department of Chemistry at Eskisehir Osmangazi University for FTIR spectra of the biopolymer. This study was supported by Eskisehir Osmangazi University Scientific Research Projects Committee (Project No: BAP 201538A101)

\section{REFERENCES}

ARIAS, S., DEL MORAL A.E., FERRER, M.R., TALLON, R., QUESADA, E., BEJAR, V. (2003). Mauran, an exopolysaccharide produced by the halophilic bacterium Halomonas maura, with a novel composition and interesting properties for biotechnology, Extremophiles, 7, 319-326, https://doi.org/10.1007/s00792003-0325-8.

ATES, O., ARGA, K.Y., ONER, E.T. (2013). The stimulatory effect of mannito on levan biosynthesis: Lessons from metabolic systems analysis of Halomonas smyrnensis AAD6 ${ }^{\mathrm{T}}$, Biotechnology Progress, 29, 1386 1397, https://doi.org/10.1002/btpr.1823.

ÇINAR, S., MUTLU, M.B. (2016). Comparative analysis of prokaryotic diversity in solar salterns in eastern Anatolia (Turkey), Extremophiles, 20, 589-601, https://doi.org/10.1007/s00792-016-0845-7.
DYALL-SMITH, M. (2009). The Halohandbook- Protocols for Haloarchaeal Genetics, Version 7.2, (https://haloarchaea.com/wpcontent/uploads/2018/10/Halohandbook 2009 v7.3mds.pdf)

ESAWY, M.A., AMER, H., GAMAL-ELDEEN, A.M., ENSHASY, H.A.E., HELMY, W.A., ABO-ZEID, M.A., AWAD, G.E. (2013). Scaling up, characterization of levan and its inhibitory role in carcinogenesis initiation stage, $\begin{array}{lll}\text { Carbohydrate } & \text { Polymers, } & 95,\end{array}$ https://doi.org/10.1016/j.carbpol.2013.02.079.

FREITAS, F., ALVES, V.D., REIS, M.A. (2011). Advances in bacterial exopolysaccharides: from production to biotechnological applications, Trends in Biotechnology, 29, 388-398, https://doi.org/10.1016/j.tibtech.2011.03.008.

GONZALEZ-DOMENECH, C.M., MARTINEZ-CHECA, F., QUESADA, E., BEJAR, V. (2008). Halomonas cerina sp. nov., a moderately halophilic, denitrifying, exopolysaccharide-producing bacterium, International Journal of

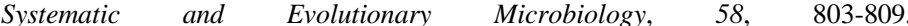
https://doi.org/10.1099/ijs.0.65322-0.

HUSSAINY, S.M., SHEREF, F.A., AMER, H., ELSAKHAWY, T.A. (2015). Biosynthesis of Applicable Levan by a New Levan Producing Moderately Halophilic Strain Chromohalobacter salexigens TA1 and its Biologica Activities, Current Science International, 4, 423-434, https://pdfs.semanticscholar.org/bf3c/88b2c1c4ff254180406354d4c46e496b18f5. pdf? ga=2.97152351.1125870020.1583329465-922782084.1576485385.

IYER, A., MODY, K., JHA, B. (2006). Emulsifying properties of a marine bacterial exopolysaccharide, Enzyme and Microbial Technology, 38, 220-222, https://doi.org/10.1016/j.enzmictec.2005.06.007.

JATHORE, N.R., BULE, M.V., TILAY, A.V., ANNAPURE U.S. (2012) Microbial levan from Pseudomonas fluorescens: Characterization and medium optimization for enhanced production, Food Science and Biotechnology, 21, 1045-1053, https://doi.org/10.1007/s10068-012-0136-8.

KANG, S.A., JANG, K.H., SEO, J.W., KIM, K.H., KIM, Y.H., RAIRAKHWADA, D et al. (2009). Levan: Applications and perspectives. In: Rehm B. Microbial Production of Biopolymers and Polymer Precursors: Applications and Perspectives, Caister Academic Press, Inc., 145-161. Norkfolk, https://www.caister.com/biopolymers.

KAZAK, H., TOKSOY ÖNER, E., DEKKER, R.F.H. (2010). Extremophiles as Sources of Exopolysaccharides, In: Ito, R., Matsuo, Y. (Eds) Handbook of Carbohydrate Polymers: Development, Properties and Applications. Nova Science Publishers, Inc., New York, 605-619, http://www.novapublishers.org/catalog/product info.php?products id=11033. KÜÇÜKAȘIK, F., KAZAK, H., GUNEY, D., FINORE, I., POLI, A. YENIGUN, O., NICOLAUS, B., TOKSOY ONER, E. (2011). Molasses as Fermentation Substrate for Levan production by Halomonas sp., Applied Microbiology and Biotechnology, 89, 1729-40, https://doi.org/10.1007/s00253010-3055-8.

MATA, J.A., BEJAR, V., LLAMAS, I., ARIAS, S., BRESSOLLIER, P TALLON, R. (2006). Exopolysaccharides produced by the recently described halophilic bacteria Halomonas ventosae and Halomonas anticariensis, Research in Microbiology, 45, 24-27, https://doi.org/10.1016/j.resmic.2006.06.004 MUTLU, B.M., MARTINEZ-GARCIA, M., SANTOS, F., PENA A., GUVEN K. ANTON, J. (2008). Prokaryotic diversity in Tuz Lake, a hypersaline environment in Inland Turkey. FEMS Microbiology Ecology, 65, 474-483, https://doi.org/10.1111/j.1574-6941.2008.00510.x

NAKAPONGA, S., PICHYANGKURAA, R., ITO, K., IIZUKAB, M. PONGSAWASDIA, P. (2013). High expression level of levansucrase from Bacillus licheniformis RN-01 and synthesis of levan nanoparticles, International Journal of Biological Macromolecules, 54, 30-36, https://doi.org/10.1016/j.ijbiomac.2012.11.017

NASIR, D.Q., WAHYUNINGRUM, D., HERTADI, R. (2015). Screening and characterization of levan secreted by halophilic bacterium of Halomonas and Chromohalobacter genuses originated from bledug kuwu mud crater, Procedia Chemistry, 16, 272-278, https://doi.org/10.1016/j.proche.2015.12.050

POLI, A., KAZAK, H., GÜRLEYENDAĞ, B., TOMMONARO, G., PIERETTI, G., TOKSOY ÖNER, E. NICOLAUS B. (2009). High level synthesis of levan by a novel Halomonas species growing on defined media, Carbohydrate Polymers, 78, 651-657, https://doi.org/10.1016/j.carbpol.2009.05.031

POLI, A., NICOLAUS, B., DENIZCI, A.A., YAVUZTURK, B., KAZAN, D. (2013). Halomonas smyrnensis sp. nov., a moderately halophilic, exopolysaccharide-producing bacterium. International Journal of Systematic and Evolutionary Microbiology, 63, 10-18, https://doi.org/10.1099/ijs.0.037036-0

RADCHENKOVA, N., BOYADZHIEVA, I., ATANASOVA, N., POLI, A. FINORE, I., DIDONATO, P., NICOLAUS, B., PANCHEV, I., KUNCHEVA, M., KAMBOUROVA, M. (2018). Extracellular polymer substance synthesized by a halophilic bacterium Chromohalobacter canadensis 28, Applied $\begin{array}{llll}\text { Microbiology and Biotechnology, 102, 4937-4949, } & \text {, }\end{array}$ https://doi.org/10.1007/s00253-018-8901-0

LANE, D.J., PACE, B., OLSEN, G.J., STAHL, D., SOGIN, M., PACE, N.R. (1985). Rapid determination of 16 S ribosomal RNA sequences for phylogenetic analyses, Proceedings of the National Academy of Sciences USA, 82, 6955-6959, https://doi.org/10.1073/pnas.82.20.6955 
REHM, B.H. (2010). Bacterial polymers: biosynthesis, modifications and applications, Nature Reviews Microbiology, 8, 578-592, https://doi.org/10.1038/nrmicro2354

SARILMISER, H.K., ATES, O., OZDEMIR, G., ARGA, K.Y., ONER, E.T

(2015). Effective stimulating factors for microbial levan production by Halomonas smyrnensis AAD6, Journal of Bioscience and Bioengineering, 119, 455-463, https://doi.org/10.1016/j.jbiosc.2014.09.019

SEZER, A.D., KAZAK, H., TOKSOY ONER, E., AKBUĞA, J. (2011). Levanbased nanocarrier system for peptide and protein drug delivery: Optimization and influence of experimental parameters on the nanoparticle characteristic, $\begin{array}{llr}\text { Carbohydrate Polymers, } & 84, & 358-363,\end{array}$

https://doi.org/10.1016/j.carbpol.2010.11.046 